\title{
Entomological approach to the impact of ionophore-feed additives on greenhouse gas emissions from pasture land in cattle
}

\author{
Junichi Takahashi ${ }^{1 *}$ and Mitsuhiro Iwasa ${ }^{2}$ \\ ${ }^{1}$ School of Animal and Food Hygiene, Obihiro University of Agriculture and Veterinary Medicine, Obihiro \\ 080-8555, Japan \\ ${ }^{2}$ Laboratory of Entomology, Obihiro University of Agriculture and Veterinary Medicine, Obihiro 080-8555, \\ Japan
}

Received: Sep 5, 2020

Revised: Oct 16, 2020

Accepted: Nov 4, 2020

*Corresponding author

Junichi Takahashi

School of Animal and Food Hygiene,

Obihiro University of Agriculture and

Veterinary Medicine, Obihiro 080-8555, Japan.

Tel: +81-155-674330

E-mail: junichi@obihiro.ac.jp

Copyright () 2021 Korean Society of Animal Sciences and Technology. This is an Open Access article distributed under the terms of the Creative Commons Attribution Non-Commercial License (http:// creativecommons.org/licenses/bync/4.0/) which permits unrestricted non-commercial use, distribution, and reproduction in any medium, provided the original work is properly cited.

ORCID

Junichi Takahashi

https://orcid.org/0000-0003-3008-843X Mitsuhiro Iwasa

http://orcid.org/0000-0002-8944-9319

Competing interests

No potential conflict of interest relevant to this article was reported.

Funding sources

A part of this work was supported by JSPS KAKENHI Grant Number JP20380147 and discretionary budgets of the President of Obihiro University of Agriculture and Veterinary Medicine.

\begin{abstract}
The suppressive effect of monensin as an ionophore-feed additive on enteric methane $\left(\mathrm{CH}_{4}\right)$ emission and renewable methanogenesis were evaluated. To clarify the suppressive effect of monensin a respiratory trial with head cage was performed using Holstein-Friesian steers. Steers were offered high concentrate diets ( $80 \%$ concentrate and $20 \%$ hay) ad libitum with or without monensin, galacto-oligosaccharides (GOS) or L-cysteine. Steers that received monensin containing diet had significantly $(p<0.01)$ lower enteric $\mathrm{CH}_{4}$ emissions as well as those that received GOS containing diet $(p<0.05)$ compared to steers fed control diets. Thermophilic digesters at $55^{\circ} \mathrm{C}$ that received manure from steers fed on monensin diets had a delay in the initial $\mathrm{CH}_{4}$ production. Monensin is a strong inhibitor of enteric methanogenesis, but has a negative impact on biogas energy production at short retention times. Effects of the activity of coprophagous insects on $\mathrm{CH}_{4}$ and nitrous oxide $\left(\mathrm{N}_{2} \mathrm{O}\right)$ emissions from cattle dung pats were assessed in anaerobic in vitro continuous gas quantification system modified to aerobic quantification device. The $\mathrm{CH}_{4}$ emission from dungs with adults of Caccobius jessoensis Harold (dung beetle) and the larvae of the fly Neomyia cornicina (Fabricius) were compared with that from control dung without insect. The cumulative $\mathrm{CH}_{4}$ emission rate from dung with dung insects decreased at $42.2 \%$ in dung beetles and $77.8 \%$ in fly larvae compared to that from control dung without insects. However, the cumulative $\mathrm{N}_{2} \mathrm{O}$ emission rate increased $23.4 \%$ in dung beetles even though it reduced $88.6 \%$ in fly larvae compared to dung without coprophagous insects. It was suggested that the antibacterial efficacy of ionophores supplemented as a growth promoter still continued even in the digested slurry, consequently, possible environmental contamination with the antibiotics might be active to put the negative impact to land ecosystem involved in greenhouse gas mitigation when the digested slurry was applied to the fields as liquid manure.
\end{abstract}

Keywords: Methane, Nitrous oxide, Monensin, Cattle dung, Pasture, Coprophagous insects 
Acknowledgements

Our special thanks are extended to Dr. Reina Morikawa and Dr. Takaki Yamashiro of Obihiro University of Agriculture and Veterinary Medicine for their valuable suggestions and technical support.

Availability of data and material Upon reasonable request, the datasets of this study can be available from the corresponding author.

\section{Authors' contributions}

Conceptualization: Takahashi J.

Data curation: Takahashi J, Iwasa M.

Formal analysis: Takahashi J, Iwasa M.

Methodology: Takahashi J, Iwasa M.

Software: Takahashi J.

Validation: Takahashi J.

Investigation: Takahashi J, Iwasa M.

Writing - original draft: Takahashi J, Iwasa M. Writing - review \& editing: Takahashi J.

Ethics approval and consent to participate This article does not require IRB/IACUC approval because there are no human and animal participants.

\section{INTRODUCTION}

Methane $\left(\mathrm{CH}_{4}\right)$ is the second significant greenhouse gas (GHG) succeeded to carbon dioxide $\left(\mathrm{CO}_{2}\right)$ emitted from human activities [1]. However, $\mathrm{CH}_{4}$ is one of the most important GHG along with nitrous oxide $\left(\mathrm{N}_{2} \mathrm{O}\right)$ attributable to animal agriculture. According to the newest value cited in the report of IPCC/AR4-Working Group 1 [2], total $\mathrm{CH}_{4}$ emission of anthropogenic sources accounts 428 teragram $(\mathrm{Tg})$ year $^{-1}$ and ruminant animals emit $189 \mathrm{Tg}_{\mathrm{gear}}{ }^{-1}$. Chynoweth [3] presumed that roughly $76 \%$ of the emission can be estimated to be derived from rumen fermentation in ruminants and the rest $24 \%$ from manure handling system. Mitigation of belching $\mathrm{CH}_{4}$ emission derived from rumen fermentation of ruminant livestock is the most important targeted strategies of world livestock industries in developed and developing countries towards Paris Agreement. Polyether ionophore antibiotics such as monensin, salinomycin, lasalocid have been known to reduce rumen methanogenesis when they have been fed as a feed additive [4]. So far, many manipulators which have potential abilities to mitigate $\mathrm{CH}_{4}$ have been proposed for ruminant feed additives as alternatives of ionophores which have tended to be prohibited as growth promotors due to the emergence of resistant bacteria [5]. However, firstly, in the feed and feeding industries polyether-based ionophores such as monensin, salinomycin and lasalocid have been used world widely to be able to reduce the production cost due to the improvement of feed efficiency as growth promotors rather than ruminal $\mathrm{CH}_{4}$ inhibiter in the world ruminant livestock production. In general, these ionophores cannot be absorbed by digestive tract of animals and then they cannot migrate to livestock products, thus it seems unlikely that the migration problems of the ionophores would appear in animal and human health. However, unabsorbed ionophores excreted to feces might have a negative impact on land ecosystem when they have been still active in the manures at fertilization.

According to the data of FAOSTAT (http://www.fao.org/faostat/en/\#data/RL) [6], world land area under permanent meadows and pastures account for nearly 3.3 billion ha year ${ }^{-1}$ and $67 \%$ of agriculture land. Additionally, Table 1 shows that world cattle manure left on pasture in 2016 account for $8.6 \mathrm{Tg} \mathrm{year}^{-1}$ from dairy cattle and $35.9 \mathrm{Tg}_{\mathrm{gear}}{ }^{-1}$ from non-dairy cattle in nitrogen $(\mathrm{N})$ basis. Cattle dung left on pasture emit $\mathrm{CH}_{4}$ and $\mathrm{N}_{2} \mathrm{O}$ other than $\mathrm{CO}_{2}$ as anthropogenic sources of GHG [7-12]. Studies on GHG emission from cattle dung have focused on field surveys of GHG emission during dung composting in livestock barns and its inhibition [13-17].

Insects are responsible for pollinating 80\% wild plants and providing food resources to $60 \%$ birds other than controlling pests as predatory insects instead of chemical pesticides and preventing desertification by entomological soil rehabilitation as the vital roles in land ecosystem. Especially, many dung-feeding insects (coprophagous insects) inhabit cattle dung pats in pasture lands. In these various coprophagous insects, dung beetles and fly larvae play an important role contributing to disappear cattle dung from the fields through their feeding behavior and moving in dung [1820]. Dung beetles especially decompose coarse dung fibers and return nitrogen and water in dung to the soil through their behavior to bury dung in the soil [21-27]. Meanwhile, fly larvae actively move within dung and feed dung to incorporate its $\mathrm{N}$ components into the body, thereby $\mathrm{N}$ content in dung will decrease [28].

For cattle dung pats in pastures, only GHG emission from dung pats and the concentration [7,29-31] and loss of $\mathrm{N}$ and ammonia by volatile gases related to dung beetle activities have been reported [32,33]. Penttila et al. [34] recently reported that dung beetles increase $\mathrm{CO}_{2}$ and $\mathrm{N}_{2} \mathrm{O}$ emission from cattle dung pats but decrease $\mathrm{CH}_{4}$ emission. So far, the relationship between the activity of insects living in dung and GHG emission remains to be elucidated. However, recently, Iwasa et al. [35] have quantitatively demonstrated the contribution of coprophagous insects to 
Table 1. Cattle manure left on pasture in the world [6]

\begin{tabular}{|c|c|c|c|c|c|c|}
\hline $\mathbf{N}$ & $\begin{array}{c}\text { Head } \\
\text { (Milion) }\end{array}$ & $\begin{array}{c}N \\
\left(\operatorname{Tg}^{-1} \text { year }^{-1}\right)\end{array}$ & $\begin{array}{c}\mathrm{N} \\
\left(\operatorname{kg~head}^{-1} \text { year }^{-1}\right)\end{array}$ & $\begin{array}{c}\mathrm{N}_{2} \mathrm{O} \\
\left(\mathrm{Gg}^{-1} \text { year }^{-1}\right)\end{array}$ & $\begin{array}{c}\mathrm{N}_{2} \mathrm{O} \\
\left(\mathrm{g} \mathrm{head}^{-1} \text { year }^{-1}\right) \\
\end{array}$ & $\begin{array}{c}\mathrm{N}_{2} \mathrm{O} \\
\left(\mathrm{g} \mathrm{head}^{-1} \text { day }^{-1}\right)\end{array}$ \\
\hline Stock & 274 & & & & & \\
\hline Manure $\mathrm{N}$ left on pasture & & 8.59 & 31.38 & & & \\
\hline Manure $\mathrm{N}$ left on pasture that leaches & & 2.58 & 9.41 & & & \\
\hline Manure $\mathrm{N}$ left on pasture that volatilises & & 1.72 & 6.28 & & & \\
\hline Direct emmision of $\mathrm{N}_{2} \mathrm{O}$ & & & & 270.0 & 986.1 & 2.7 \\
\hline Indirect emmision of $\mathrm{N}_{2} \mathrm{O}$ & & & & 57.4 & 209.5 & 0.6 \\
\hline $\mathrm{N}_{2} \mathrm{O}$ leaches ${ }^{2)}$ & & & & 30.4 & 110.9 & 0.3 \\
\hline $\mathrm{N}_{2} \mathrm{O}$ volatilises ${ }^{3)}$ & & & & 27.0 & 98.6 & 0.3 \\
\hline \multicolumn{7}{|l|}{ Non-dairy cattle } \\
\hline Manure left on pasture that volatilises & & 7.18 & 26.21 & & & \\
\hline Emmision of $\mathrm{N}_{2} \mathrm{O}^{1}$ ) & & & & $1,367.6$ & $1,138.6$ & 3.1 \\
\hline Direct emmision of $\mathrm{N}_{2} \mathrm{O}$ & & & & $1,127.9$ & 939.1 & 2.9 \\
\hline Indirect emmision of $\mathrm{N}_{2} \mathrm{O}$ & & & & 239.7 & 199.6 & 0.5 \\
\hline $\mathrm{N}_{2} \mathrm{O}$ leaches $^{2)}$ & & & & 126.9 & 105.6 & 0.3 \\
\hline $\mathrm{N}_{2} \mathrm{O}$ volatilises ${ }^{3)}$ & & & & 112.7 & 93.8 & 0.3 \\
\hline
\end{tabular}

${ }^{1)} \mathrm{N}_{2} \mathrm{O}$ from manure left on pasture.

${ }^{2)} \mathrm{N}_{2} \mathrm{O}$ that leahes from manure left on pasture.

${ }^{3)} \mathrm{N}_{2} \mathrm{O}$ that volatilises from manure left on pasture.

mitigate GHG emitted from dung pats left on the dairy cattle pastures using in vitro continuous gas quantification system.

The present review deals with environmental impacts of ionophore-feed additives on the methanogenesis in rumen and anaerobic digester and entomological approach to assess the global mitigation potentials of coprophagous insects on $\mathrm{CH}_{4}$ and $\mathrm{N}_{2} \mathrm{O}$ emission from cattle pasture.

\section{Effect of monensin containing diet on rumen $\mathrm{CH}_{4}$ emission and anaerobic fermen- tation of manure in steers}

In an attempt to seek safe manipulators of $\mathrm{CH}_{4}$ emission, we tried to clarify the effects of galactooligosaccharides (GOS) and L-cysteine vs. monensin on rumen $\mathrm{CH}_{4}$ emission and renewable $\mathrm{CH}_{4}$ production from anaerobic fermentation of manures [17,36]. As experimental animals four Holstein-Friesian steers $(291 \pm 11 \mathrm{~kg}$ ) were fed on high concentrate diet (20\% mixed hay and 80\% concentrates) with or without $200 \mathrm{~g}$ GOS, L-cysteine as a hydrochloride (1.156 g kg ${ }^{-1}$ concentrate) or monensin (30 $\mathrm{g} \mathrm{kg}^{-1}$ concentrate), and assigned according to $4 \times 4$ Latin Square Design. Rumen $\mathrm{CH}_{4}$ emission were determined using open-circuit ventilated-hood respiratory system for indirect calorimetry equipped with infrared $\mathrm{CH}_{4}$ analyzer (VIA-300, Horiba, Japan) [37].

Table 2 shows daily amount of rumen $\mathrm{CH}_{4}$ emitted from experimental steers. Control steers without supplements was emitted $98.1 \mathrm{~L} \mathrm{~d}^{-1} . \mathrm{CH}_{4}$ emission in steers fed on monensin diet was $17.8 \%$ lower $(p<0.05)$ than those fed control diet. For mitigating effect of monensin on enteric $\mathrm{CH}_{4}$ emission, it is widely indicated that the inhibition of rumen methanogenesis by monensin is not due to a specific toxic action on the methanogenic archaea such as hydrogen peroxide $\left(\mathrm{H}_{2} \mathrm{O}_{2}\right)$ 
Table 2. Rumen $\mathrm{CH}_{4}$ emission in steers fed high concentrate diets ( $80 \%$ DM basis) with or without GOS, L-cysteine or monensin

\begin{tabular}{ccccccc}
\hline & Control & GOS & L-Cysteine & Monensin & SEM & $p$-value \\
\hline $\mathrm{CH}_{4}\left(\mathrm{Ld}^{-1}\right)$ & $98.1^{\mathrm{a}}$ & $90.8^{\mathrm{bc}}$ & $95.9^{\mathrm{ab}}$ & $80.6^{\mathrm{c}}$ & 3.37 & 0.003 \\
\hline
\end{tabular}

${ }^{a-c}$ Means within a row with different superscripts differ $(p<0.05)$

DM, dry matter; GOS, galacto-oligosaccharides.

produced by Lactobacillus plantarum TUA14901 [38]. Rather, the indirect actions were more likely the population change related to the decrease in ciliate protozoa and shortage of available hydrogen from formate or acrylate pathway in the rumen [39-41], Recent studies have suggested that rumen microbiome will adapt to monensin over time [42], though Gram-positive bacteria are reduced via disruption of the ion-flux mechanism in the short-term $[43,44]$. Consequently, the mitigating effect of dietary monensin on $\mathrm{CH}_{4}$ emission will be disappeared by long-term feeding.

Even in steers fed on GOS diet, $\mathrm{CH}_{4}$ emission was also exhibited 7.4\% lower $(p<0.05)$ than those fed also control diet. Consequently, energy retention (\% gross energy intake) in steers fed on monensin diet tended to be $9.5 \%$ higher compared to those fed control diet. This remedial effect of monensin on feed efficiency in energy metabolism has been a principal driving force behind spread over the world ruminant production as an ionophore supplement, although the incidence of resistant bacteria is being currently at issue.

Table 3 shows quantitative evaluation of anaerobic $\mathrm{CH}_{4}$ production from manure collected from steers fed on high concentrate diet with or without GOS, L-cysteine or monensin. For the anaerobic fermentation, thermophilic $\left(55^{\circ} \mathrm{C}\right)$ batch digesters $(1 \mathrm{~L}$ capacity) filled with $300 \mathrm{~g}$ inoculums (9.3 $\mathrm{g}$ volatile solid [VS]) and $300 \mathrm{~g}$ sample ( $30 \mathrm{~g}$ total solids) were used. The digesters operated for 50 days. For desulfurization iron oxide was used to capture hydrogen sulfide from biogas. Total volume of gas production was measured using wet gas meter. $\mathrm{CH}_{4}$ concentration was analyzed by gas chromatograph (GC-8A, Shimadzu, Kyoto, Japan).

Manure composition from steers fed monensin-containing diets had higher $(p<0.01)$ volatile solids and neutral detergent fiber and also higher $(p<0.05)$ hemicellulose contents than that from steers fed on control diets. Progressive $\mathrm{CH}_{4}$ production $\left(\mathrm{L} \mathrm{g}^{-1} \mathrm{VS}\right.$ fed $\left.\left[\mathrm{VS}_{\mathrm{f}}\right]\right)$ in batch digesters fed with manure from steers fed monensin-containing diets delayed in initiating $\mathrm{CH}_{4}$ production. On day 10 of anaerobic fermentation, monensin-containing digesters produced lower $(p<0.001)$ methane compared to other digesters. Until d 30 the difference between monensin containing digesters and other treatments was significant $(p<0.05)$, though the difference was gradually narrowing with time of fermentation. The deactivation with degradation of ionophore antibiotics is regarded to be affected by temperature and retention time of anaerobic fermentation. In a global

Table 3. Progressive $\mathrm{CH}_{4}$ yield ( $\mathrm{L} \mathrm{g}^{-1}$ volatile solids fed) in batch digesters fed manure from steers supplemented with or without (control) GOS, L-cysteine or monensin

\begin{tabular}{ccccccc}
\hline \multirow{2}{*}{ Day } & \multicolumn{9}{c}{ Treatment } \\
\cline { 2 - 7 } & Control & GOS & L-cysteine & Monensin & SEM & $p$-value \\
\hline 10 & $0.187^{\mathrm{a}}$ & $0.207^{\mathrm{a}}$ & $0.214^{\mathrm{a}}$ & $0.061^{\mathrm{b}}$ & 0.016 & 0.001 \\
20 & $0.230^{\mathrm{a}}$ & $0.251^{\mathrm{a}}$ & $0.259^{\mathrm{a}}$ & $0.091^{\mathrm{b}}$ & 0.023 & 0.010 \\
30 & $0.252^{\mathrm{a}}$ & $0.274^{\mathrm{a}}$ & $0.281^{\mathrm{a}}$ & $0.145^{\mathrm{b}}$ & 0.029 & 0.034 \\
40 & 0.266 & 0.287 & 0.294 & 0.174 & 0.037 & 0.156 \\
50 & 0.275 & 0.295 & 0.302 & 0.185 & 0.197 & 0.039 \\
\hline
\end{tabular}

${ }_{\mathrm{a}, \mathrm{b}}$ Means within a row with different superscripts differ by the corresponding $p$-value.

GOS, galacto-oligosaccharides. 
trend mesophilic and thermophilic biogas systems have become widespread. Impact of hyperthermophilic fermentation around $60^{\circ} \mathrm{C}$ for cattle manure to possible degradation of polyetherbased ionophores has room for further investigation.

\section{Global impact of coprophagous insects on $\mathrm{CH}_{4}$ and $\mathrm{N}_{2} \mathrm{O}$ emission from dung pads of dairy cattle}

Freshly passed dang pats were collected on the day of the experiment on the pasture where milking cows were grazing on the temperate mixed pasture. Two species coprophagous insects, i. e. adults of dung beetles Caccobius jessoensis Harold and fly larvae of Neomyia cornicina (Fabricius), were examined in in vitro gas metabolism trials. Both species were commonly found in the temperate pasture land and are relatively abundant species. They were collected in the same pasture. Dung beetles were collected from cattle dung pats a day before the experiment. For fly larvae and fly eggs were collected a day before the experiment, and newly hatched first instar larvae were designated as test samples. Fig. 1 shows schematic illustration of vented glass chamber used for this experiment which is connected to in vitro continuous gas quantification system and experimental coprophagous insects. Since this experiment examined living insects, fresh air was continuously provided to the vented glass containers at $0.5 \mathrm{~mL} \mathrm{~min}^{-1}$ by air cylinder. As experimental materials, $1 \mathrm{~kg}$ of black soil, $1 \mathrm{~kg}$ of dung, and the insects were introduced in sequence. Five hundred fly larvae and 30 adult dung beetles ( 10 males and 20 females) were introduced. Insect density was determined by considering the volume of the container and amount of dung.

Fig. 2 shows in vitro continuous gas quantification system (Takasugi MFG, Tokyo, Japan) [41] installed infrared $\mathrm{CO}_{2}$ analyzer and infrared $\mathrm{CH}_{4}$ analyzer [38, 45] for seven straight days by operating the three containers simultaneously. This gas flows through the individual insectary containers separately, and data from each container would not be scrambled. In parallel with the measurement with in vitro continuous gas quantification system, exhaust gases from system were quantitatively collected in the Tedlar bag every 12 or 24 hours to determine $\mathrm{N}_{2} \mathrm{O}$ concentration. The $\mathrm{N}_{2} \mathrm{O}$ concentration in the Tedlar bag was analyzed by ECD gas chromatograph (Shimadzu

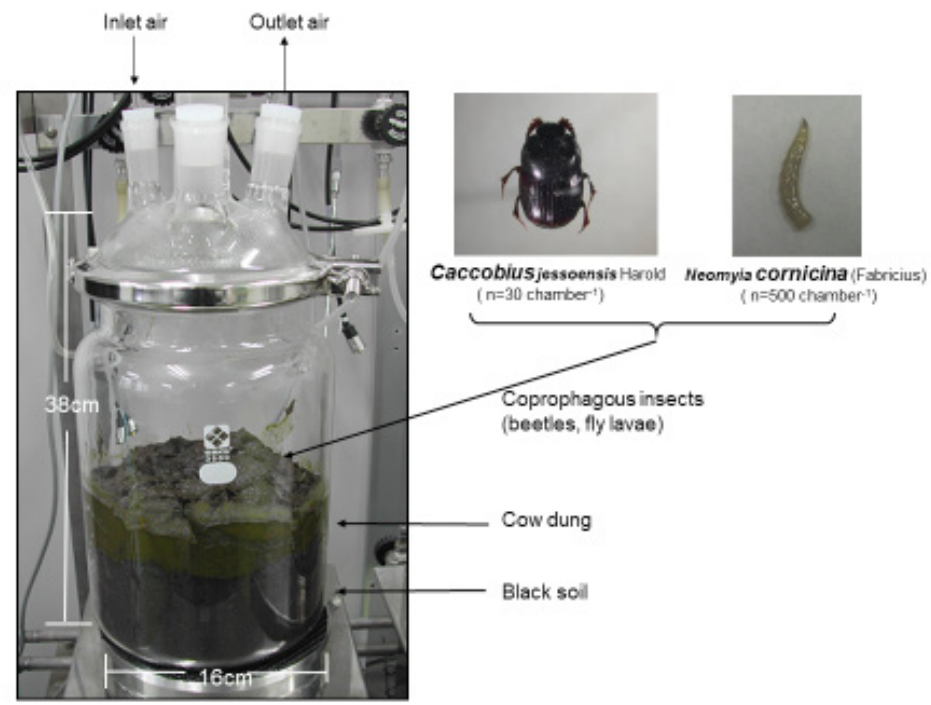

Fig. 1. Vented glass chamber connected to in vitro continuous gas quantification system and experimental coprophagous insects. 


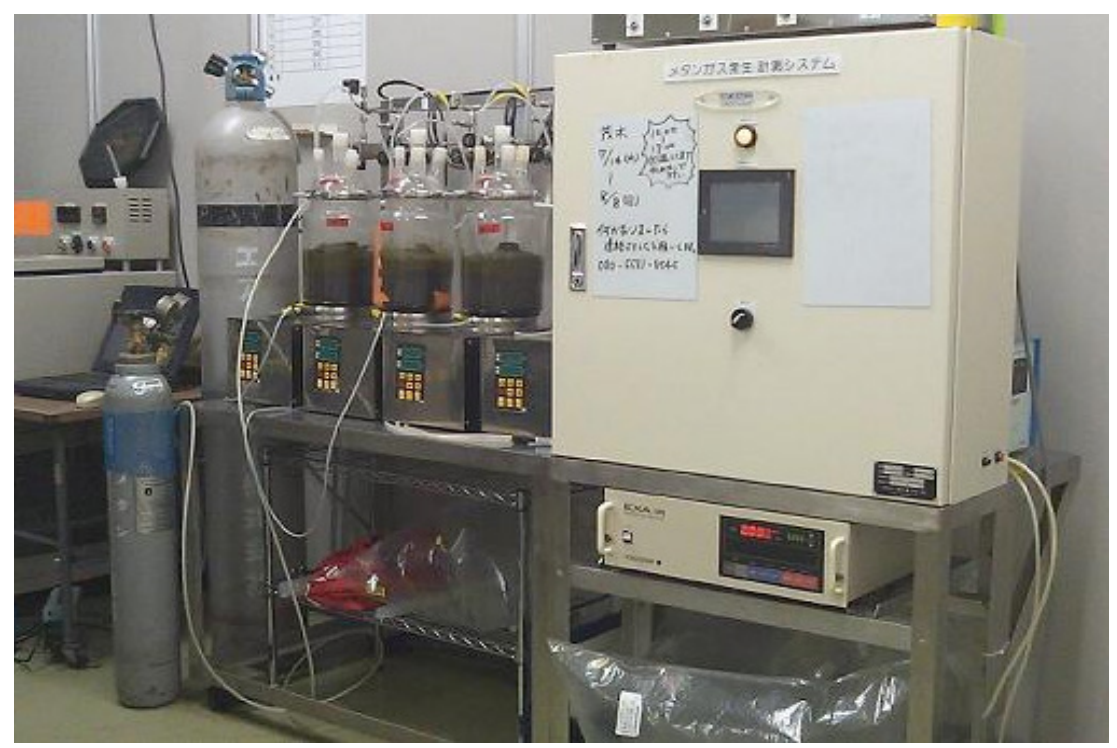

Fig. 2. In vitro continuous gas quantification system installed infrared $\mathrm{CO}_{2}$ analyzer and infrared $\mathrm{CH}_{4}$ analyzer [41].

GC-1024, Kyoto, Japan) equipped with an attachment of direct inlet device system.

Table 4 shows effect of coprophagous insects on cumulative flux of GHG from dung in chambers for 7 days. The cumulative $\mathrm{CH}_{4}$ emission from dung was decreased by the feeding behavior of coprophagous insects. Each reduction rate of cumulative $\mathrm{CH}_{4}$ emission is $42.2 \%$ in dung beetles or $77.8 \%$ in fly larvae compared to dung without coprophagous insects. Meanwhile, the cumulative $\mathrm{N}_{2} \mathrm{O}$ emission rate increased $23.4 \%$ in dung beetles even though it reduced $88.6 \%$ in fly larvae compared to dung without coprophagous insects. Dung $\mathrm{N}$ content collected from dairy pasture was analyzed at $2.14 \%$ in dry matter $(\mathrm{DM})$ basis and total yearly fecal $\mathrm{N}$ was 8.59 $\mathrm{Tg}$ in dairy cattle and $35.89 \mathrm{Tg}$ in non-dairy cattle (Table 1). Hence, approximate yearly total fecal $\mathrm{DM}$ can be figured out at $401.40 \mathrm{Tg}$ in dairy cattle and 1,677.10 $\mathrm{Tg}$ in non-dairy cattle, though that is only guide due to the different feeding condition. According to FAOSTAT (Table1) total $\mathrm{N}_{2} \mathrm{O}$ emission from dung left on pasture was 327.4 gigagram $(\mathrm{Gg})$ in dairy cattle and $1.27 \mathrm{Tg}$ in non-dairy cattle. Thus, total potential contribution of fly larvae to mitigate $\mathrm{N}_{2} \mathrm{O}$ can be roughly estimated yearly at $290.08 \mathrm{Gg}$ from dairy pasture and $1.12 \mathrm{Tg}$ from non-dairy pasture, $\mathrm{For}_{\mathrm{CH}_{4}}$ emitted from cattle dung left on pasture, statistical evidences have not been reported as references, and therefore total $\mathrm{CH}_{4}$ emission has been estimated from dung $\mathrm{CH}_{4}$ without insects in the present study (Table 4) and fecal DM calculated using FAOSTAT (Table 1). In this calculation, average

Table 4. Effect of coprophagous insects on cumulative emission of $\mathrm{CH}_{3}$ and $\mathrm{N}_{2} \mathrm{O}$ from cow dung for 7 days

\begin{tabular}{|c|c|c|c|c|c|c|}
\hline \multirow{2}{*}{ Treatment } & \multicolumn{4}{|c|}{ Cumulative flux $(\mathrm{mL})^{1)}$} & \multicolumn{2}{|c|}{$\mathrm{mgCO}_{2} \mathrm{eq}^{2)}$} \\
\hline & $\mathrm{CH}_{4}$ & $\triangle \%$ & $\mathrm{~N}_{2} \mathrm{O}$ & $\triangle \%$ & $\mathrm{CH}_{4}$ & $\mathrm{~N}_{2} \mathrm{O}$ \\
\hline Dung beetles & 2.324 & 42.3 & 0.116 & 23.4 & 41.5 & 67.6 \\
\hline Fly larvae & 0.893 & 77.8 & 0.011 & 88.3 & 15.9 & 6.3 \\
\hline No insects & 4.025 & - & 0.094 & - & 71.9 & 54.8 \\
\hline
\end{tabular}

${ }^{11}$ Cumulative flux of greenhouse gas (GHG) emitted from dung for 7 days.

${ }^{2)}$ Calculated with global warming potential(GWP) values $\left(\mathrm{CH}_{4}: 25, \mathrm{~N}_{2} \mathrm{O}: 298\right)$ relative to $\mathrm{CO}_{2}$ adapted from IPCC Fifth Assessment 2014 (AR5). GHG, greenhouse gas. 
moisture content of fresh dung in grazing cattle was presumed at $80 \%$. Thus, total $\mathrm{CH}_{4}$ emission from dung without insects left on pasture was $300.9 \mathrm{Gg}$ in dairy cattle and $1.26 \mathrm{Tg}$ in non-dairy cattle. With respect to the contribution of coprophagous insects to $\mathrm{CH}_{4}$ emission from dung left on pasture, the potential mitigating ability of dung beetles can be estimated yearly at $126.98 \mathrm{Gg}$ from dairy pasture and $531.72 \mathrm{Gg}$ from non-dairy pasture. In the case of fly larvae dung $\mathrm{CH}_{4}$ emission presumed to be mitigated by $234.10 \mathrm{Gg}$ in dairy cattle and $980.28 \mathrm{Gg}$ in non-dairy cattle.

\section{CONCLUSION}

It might be difficult to apply statistics of FAOSTAT to results form in vitro study, because the global distribution of the coprophagous insects in the different climatic zone must be considered based on more detailed investigation. However, it is worth to imagine the impact of roles of coprophagous insects in land ecosystem to mitigate $\mathrm{CH}_{4}$ and $\mathrm{N}_{2} \mathrm{O}$ emitted from cattle dung left on pastures. Effects of ionophore antibiotics residues as feed additives on land ecosystem such as coprophagous insects involved in GHG mitigation remain to be elucidated.

\section{REFERENCES}

1. Wuebbles DJ, Hayhoe K. Atmospheric methane and global change. Earth-Sci Rev. 2002;57:177-210. https://doi.org/10.1016/S0012-8252(01)00062-9

2. Solomon S, Qin D, Manning M, Chen Z, Marquis M, Averyt KB, et al. Climate Change 2007: the physical science basis. Contribution of working group I to the fourth assessment report of the Intergovernmental Panel on Climate Change. Cambridge, UK: Cambridge University Press; 2007.p. 542.

3. Chynoweth DP. Environmental impact of biomethanogenesis. Environ Monit Assess. 1996;42:3-18. https://doi.org/10.1007/BF00394039

4. Bergen WG, Bates DB. Ionophores: their effect on production efficiency and mode of action.J Anim Sci. 1984; 58:1465-83. https://doi.org/10.2527/jas1984.5861465x

5. Russell JB, Houlihan AJ. Ionophore resistance of ruminal bacteria and its potential impact on human health. FEMS Microbiol Rev. 2003;27:65-74. https://doi.org/10.1016/S01686445(03)00019-6

6. Food and Agriculture Organization of the United Nations [FAO]. FAOSTAT database [Internet]. 2016 [cited 2020 Aug 4]. http://www.fao.org/faostat/en/\#data/EL

7. MacDiarmid BN, Watkin BR. The cattle dung patch: 2. effect of a dung patch on the chemical status of the soil, and ammonia nitrogen losses from the patch. Grass Forage Sci. 1972;27:43-8. https://doi.org/10.1111/j.1365-2494.1972.tb00684.x

8. Holter P. Concentration of oxygen, carbon dioxide and methane in the air within dung pats. Pedobiologia (Jena). 1991;35:381-6.

9. Petersen SO, Sommer SG, Aaes O, Søegaard K. Ammonia losses from urine and dung of grazing cattle: effect of N intake. Atmos Environ. 1998;32:295-300. https://doi.org/10.1016/ S1352-2310(97)00043-5

10. Saggar S, Bolan NS, Bhandral R, Hedley CB, Luo J. A review of emissions of methane, ammonia, and nitrous oxide from animal excreta deposition and farm effluent application in grazed pastures. N Z J Agric Res. 2004;47:513-44. https://doi.org/10.1080/00288233.2004.9513618

11. van Groenigen JW, Velthof GL, van der Bolt FJ, Vos A, Kuikman PJ. Seasonal variation in $\mathrm{N} 2 \mathrm{O}$ emissions from urine patches: effects of urine concentration, soil compaction and dung. Plant Soil. 2005;273:15-27. https://doi.org/10.1007/s11104-004-6261-2 
12. Bellarby J, Tirado R, Leip A, Weiss F, Lesschen JP, Smith P. Livestock greenhouse gas emissions and mitigation potential in Europe. Glob Chang Biol. 2013;19:3-18. https://doi. org/10.1111/j.1365-2486.2012.02786.x

13. Massé DI, Croteau F, Patni NK, Masse L. Methane emission from dairy cow and swine manure slurries stored at $10^{\circ} \mathrm{C}$ and $15^{\circ} \mathrm{C}$. In: Takahashi J, Young BA, editors. Greenhouse gases and animal agriculture. Amsterdam, Nederland: Elsevier; 2002. p. 307-11.

14. Shiraishi M, Wakimoto N, Takimoto E, Kobayashi H, Osada T. Measurement and regulation of environmentally hazardous gas emissions from beef cattle manure composting. Int Congr Ser. 2006;1293:303-6. https://doi.org/10.1016/j.ics.2006.02.039

15. Kreuzer M, Dohme F, Kulling DR, Sutter F, Lischer P, Menzi H. Animal and manure-derived methane emissions as affected by dietary fatty acids and manure storage system. In:Takahashi J, Young BA, editors. Greenhouse gases and animal agriculture. Amsterdam, Nederland: Elsevier; 2002.p. 145-9.

16. Kreuzer M, Hindrichsen IK. Methane mitigation in ruminants by dietary means: the role of their methane emission from manure. Int Cong Ser. 2006;1293:199-208. https://doi. org/10.1016/j.ics.2006.01.015

17. Mwenya B, Sar C, Pen B, Morikawa R, Takaura K, Kogawa S, et al. Effect of feed additives on ruminal methanogenesis and anaerobic fermentation of manure in cows and steers. Int Cong Ser 2006;1293:209-12. https://doi.org/10.1016/j.ics.2006.03.027

18. Papp L. Ecological and production biological data on the significance of flies breeding in cattle droppings. Acta Zool Budapest. Acad Sci Hung. 1971;17:91-105.

19. Nakamura Y. Decomposition of organic materials and soil fauna in pasture. II. disapearance of cow dung. Pedobiologia (Jena). 1975;15:129-32.

20. Holter P. Effect of dung-beetles (Aphodius spp.) and earthworms on the disappearance of cattle dung. Oikos. 1979;32:393-402. https://doi.org/10.2307/3544751

21. Yokoyama K, Miyauchi N. A preliminary study on cow dung decomposition by Onthophagus lenzii Harold (Coleoptera: Scarabaedidae): Physical breakdown of organic matter. Edaphologia (Japan). 1990;43:51-4.

22. Yokoyama K, Miyauchi N. Decomposition of organic matter in cow dung colonized by Onthophagus lenzii Harold (Coleoptera: Scarabaeidae). Edaphologia (Japan). 1991;47:33-9.

23. Kazuhira Y, Hdeaki K, Takuro K, Toshiharu A. Nitrogen mineralization and microbial populations in cow dung, dung balls and underlying soil affected by paracoprid dung beetles. Soil Biol Biochem. 1991;23:649-53. https://doi.org/10.1016/0038-0717(91)90078-X

24. Brown J, Scholtz CH, Janeau JL, Grellier S, Podwojewski P. Dung beetles (Coleoptera: Scarabaeidae) can improve soil hydrological properties. Appl Soil Ecol. 2010;46:9-16. https:// doi.org/10.1016/j.apsoil.2010.05.010

25. Bornemissza GF, Williams $\mathrm{CH}$. An effect of dung beetle activity on plant yield. Pedobiologia. 1970;10:1-7.

26. Bang HS, Lee JH, Kwon OS, Na YE, Jang YS, Kim WH. Effects of paracoprid dung beetles (Coleoptera: Scarabaeidae) on the growth of pasture herbage and on the underlying soil. Appl Soil Ecol. 2005;29:165-71. https://doi.org/10.1016/j.apsoil.2004.11.001

27. Nichols E, Spector S, Louzada J, Larsen T, Amezquita S, Favila ME, et al. Ecological functions and ecosystem services provided by Scarabaeinae dung beetles. Biol Conserv. 2008;141:146174. https://doi.org/10.1016/j.biocon.2008.04.011

28. Macqueen A, Beirne BP. Influence of some dipterous larvae on nitrogen loss from cattle dung. Environ Entomol.1975;4:868-70. https://doi.org/10.1093/ee/4.6.868

29. Holter P. Sampling air from dung pats by silicone rubber diffusion chambers. Soil Biol Bio- 
chem. 1990;22:995-7.https://doi.org/10.1016/0038-0717(90)90143-N

30. Holter P. Methane emissions from Danish cattle dung pats in the field. Soil Biol Biochem. 1997;29:31-7. https://doi.org/10.1016/S0038-0717(96)00267-2

31. Jarvis SC, Lovell RD, Panayides R. Patterns of methane emission from excreta of grazing animals. Soil Biol Biochem. 1995;27:1581-8. https://doi.org/10.1016/0038-0717(95)00092-S

32. Gillard P. Coprophagous beetles in pasture ecosystems.J Aust Inst Agric Sci. 1967;33:30-4.

33. Yokoyama K, Kai H, Tsuchiyama H. Paracoprid dung beetles and gaseous loss of nitrogen from cow dung. Soil Biol Biochem. 1991;23:643-7. https://doi.org/10.1016/00380717(91)90077-W

34. Penttilä A, Slade EM, Simojoki A, Riutta T, Minkkinen K, Roslin T. Quantifying beetle-mediated effects on gas fluxes from dung pats. PLoS One. 2013;8:1-7. https://doi.org/10.1371/ journal.pone.0071454

35. Iwasa M, Moki Y, Takahashi J. Effects of the activity of coprophagous insects on greenhouse gas emissions from cattle dung pats and changes in amounts of nitrogen, carbon, and energy. Environ Entomol. 2015;44:106-13. https://doi.org/10.1093/ee/nvu023

36. Mwenya B, Sar C, Santoso B, Kobayashi T, Morikawa R, Takaura K, et al. Comparing the effects of $\beta$ 1-4 galacto-oligosaccharides and L-cysteine to monensin on energy and nitrogen utilization in steers fed a very high concentrate diet. Anim Feed Sci Tech. 2005;118:19-30. https://doi.org/10.1016/j.anifeedsci.2004.10.014

37. Takahashi J, Chaudhry AS, Beneke RG, Young BA. An open-circuit hood system for gaseous exchange measurements in small ruminants. Small Rumin Res. 1999;32:31-6. https://doi. org/10.1016/S0921-4488(98)00163-1

38. O'Brien M, Hashimoto T, Senda A, Nishida T, Takahashi J. The impact of Lactobacillus plantarum TUA1490L supernatant on in vitro rumen methanogenesis and fermentation. Anaerobe. 2013;22:137-40. https://doi.org/10.1016/j.anaerobe.2013.003

39. Van Nevel CJ, Demeyer DI. Effect of monensin on rumen metabolism in vitro. Appl Environ Microbiol. 1977;34:251-7.

40. Newbold CJ, Lassalas B, Jouany JP. The importance of methanogens associated with ciliate protozoa in ruminal methane production in vitro. Lett Appl Microbiol. 1995;21:230-4. https:// doi.org/10.1111/j.1472- 765X.1995.tb01048.x

41. Takahashi J, Mwenya B, Santoso B, Sar C, Umetsu K, Kishimoto T, et al. Mitigation of methane emission and energy recycling in animal agricultural systems. Asian-Australas J Anim Sci. 2005;18:1199-208. https://doi.org/10.5713/ajas.2005.1199

42. Melchior EA, Hales KE, Lindholm-Perry AK, Freetly HC, JWells JE, Hemphill CN, et al. The effects of feeding monensin on rumen microbial communities and methanogenesis in bred heifers fed in a drylot. Livestock Sci. 2018;212:131-6. https://doi.org/10.1016/j.livsci.2018.03.019

43. Bergen WG, Bates DB. Ionophores: their effect on production efficiency and mode of action. J Anim Sci. 1984;58:1465-83. https://doi.org/10.2527/jas1984.5861465x

44. Russell JB, Houlihan AJ. Ionophore resistance of ruminal bacteria and its potential impact on human health. FEMS Microbiol Rev. 2003;27:65-74. https://doi.org/10.1016/S01686445(03)00019-6

45. Pen B, Sar C, Mwenya B, Kuwaki K, Morikawa R, Takahashi J. Effects of Yucca schidigera and Quillaja saponaria extracts on in vitro ruminal fermentation and methane emission. Anim Feed Sci Technol. 2006;129:175-86. https://doi.org/10.1016/j.anifeedsci.2006.01.002 